\title{
Amylin as a Future Obesity Treatment
}

\author{
Babak Dehestani*, Nicholas RS Stratford, Carel W le Roux \\ Department of Metabolic Medicine, Conway Institute of Biomedical and Biomolecular Research, University College Dublin, Dublin, Ireland
}

Obesity is defined as abnormal or excessive fat accumulation that contributes to detrimental health impacts. One-third of the population suffers from obesity, and it is important to consider obesity as a chronic disease requiring chronic treatment. Amylin is co-secreted with insulin from $\beta$ pancreatic cells upon nutrient delivery to the small intestine as a satiety signal, acts upon sub-cortical homeostatic and hedonic brain regions, slows gastric emptying, and suppresses post-prandial glucagon responses to meals. Therefore, new pharmacological amylin analogues can be used as potential anti-obesity medications in individuals who are overweight or obese. In this narrative review, we analyse the efficacy, potency, and safety of amylin analogues. The synthetic amylin analogue pramlintide is an approved treatment for diabetes mellitus which promotes better glycaemic control and small but significant weight loss. AM833 (cagrilintide), an investigational novel long-acting acylated amylin analogue, acts as a non-selective amylin receptor. This calcitonin G protein-coupled receptor agonist can serve as an attractive novel treatment for obesity, resulting in reduction of food intake and significant weight loss in a dosedependent manner.

Key words: Obesity, Treatment, Satiety, Analogue, Weight loss

\author{
Received August 21, 2021 \\ Reviewed November 14, 2021 \\ Accepted November 19, 2021 \\ ${ }^{*}$ Corresponding author \\ Babak Dehestani \\ https://orcid.org/0000-0001-7916-0653 \\ Department of Metabolic Medicine, \\ Conway Institute of Biomedical and \\ Biomolecular Research, University \\ College Dublin, D04 V1W8, Dublin, \\ Ireland \\ Tel: +353-8-3356-7181 \\ Fax: +353-1221-4428 \\ E-mail: babak.dehestani@ucd.ie
}

\section{INTRODUCTION}

Fundamentally, obesity is caused by dysregulation of appetite control which then results in excess adipose tissue causing deterioration in health. One-third of the population suffers from obesity (body mass index, $\geq 30 \mathrm{~kg} / \mathrm{m}^{2}$ ). ${ }^{1}$ Previously, the disease was not fully understood, and this resulted in a stigmatisation of people living with obesity. ${ }^{1}$ Homeostatic centres in the brain play a key regulatory role in hunger and satiety. Only recently, however, have we gained an appreciable understanding surrounding the potential for dysfunctional gut-brain communications and obesity. ${ }^{2}$ Importantly, gaining a better understanding of how dysfunctional homeostasis causes obesity will allow for both treatment of obesity as a disease and decrease of societal stigma.

The gastrointestinal system releases a plethora of satiety hormones in response to food intake. ${ }^{3}$ Hormones such as glucagonlike peptide 1 (GLP-1), oxyntomodulin, and islet amyloid poly- peptide (amylin) relay signals to hypothalamic nuclei and other areas of the subcortical areas of the brain, resulting in feelings of increased fullness and satisfaction. ${ }^{4}$ Amylin receptors are located on specific nuclei of the dorsal-vagal-complex located within the hindbrain-the nucleus tractus solitarius (NTS), area postrema (AP), and dorsal motor nucleus of the vagus nerve. ${ }^{4}$ Amylin and the amylin receptors (AMYRs) have been identified as potential targets for treatment of obesity. Released from $\beta$ pancreatic cells, amylin is a 37-amino-acid polypeptide co-secreted with insulin, playing a primary role in glucose homeostasis by slowing gastric emptying, suppressing glucagon secretion, and initiating an anorectic signal postprandially (Fig. 1)..$^{5-11}$ The synthetic amylin analogue pramlintide is an approved treatment for diabetes mellitus which promotes better glycaemic control and small but significant weight loss. However, this small amount of wight loss is not sufficient to reverse the complications of obesity, which highlights the importance of developing new amylin analogues. ${ }^{12}$

Copyright (C) 2021 Korean Society for the Study of Obesity

() This is an Open Access article distributed under the terms of the Creative Commons Attribution Non-Commercial License (https://creativecommons.org/licenses/by-nc/4.0/) which permits unrestricted non-commercial use, distribution, and reproduction in any medium, provided the original work is properly cited. 


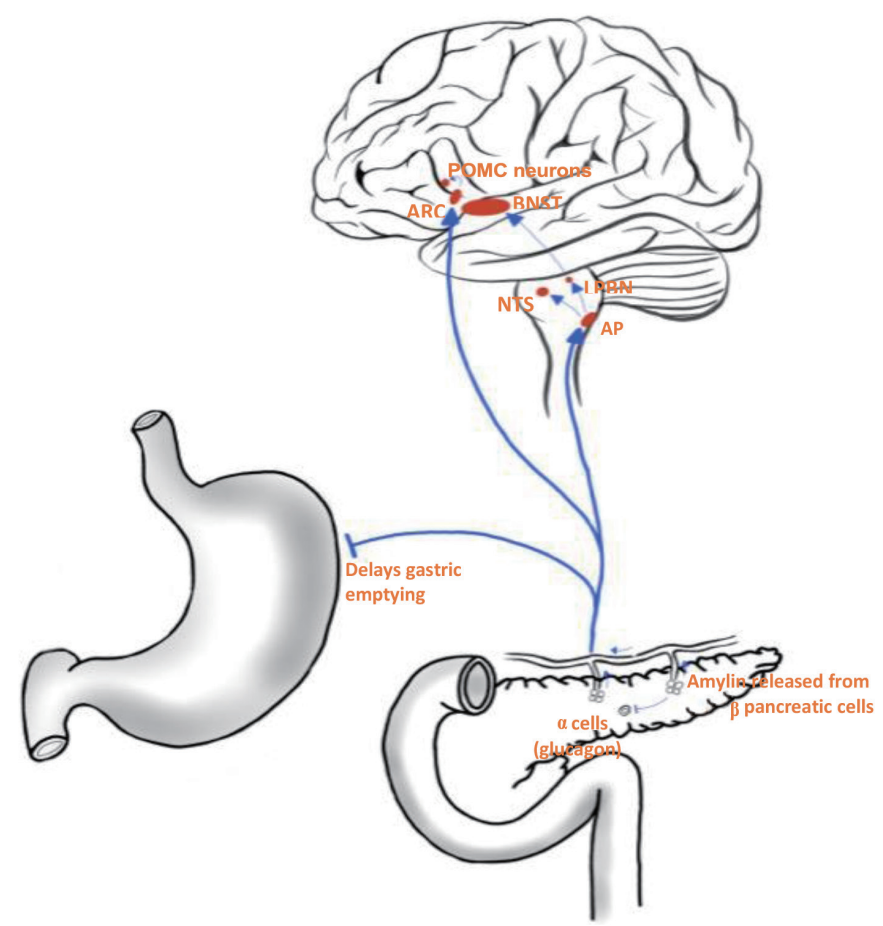

Figure 1. Amylin functions as a satiety hormone. Released into the bloodstream by $\beta$ pancreatic cells, amylin activates various homeostatic and reward centres in the brain to suppress appetite and reduce food intake. In addition, amylin acts as an inhibitory signal to delay gastric emptying and suppress the release of glucagon from a pancreatic cells. POMC, proopiomelanocortin; ARC, arcuate nucleus; BNST, bed nucleus of the stria terminalis; NTS, nucleus tractus solitarius; LPBN, lateral parabrachial nucleus; AP, area postrema.

Therefore, newer pharmacological amylin analogues such as AM833 (cagrilintide), an investigational novel long-acting acylated amylin analogue, acts as a non-selective AMYR. This calcitonin G protein-coupled receptor (CTR) agonist can serve as an attractive novel treatment for obesity which can result in reduction of food intake and weight loss in a dose-dependent manner. ${ }^{13-15}$

\section{AMYLIN AS A SATIETY HORMONE}

Hunger and satiety are regulated by negative feedback mechanisms to maintain caloric intake appropriate to the body's energy requirements. ${ }^{2,3}$ Ghrelin is the only known orexigenic gut hormone, although a complex interplay of satiety gut hormones stimulates the subcortical areas of the brain. ${ }^{2-4}$ Failure to regulate these processes can result in hypophagia or hyperphagia, leading to weight loss or weight gain, respectively. ${ }^{2-4}$ Gut hormones, such as amylin, play a key role in regulating satiety postprandially. Amylin is co-secreted with insulin from $\beta$ pancreatic cells upon nutrient delivery to the small intestine. AMYRs are located in the of the brainstem. ${ }^{16}$ As a circumventricular organ, the AP detects amylin through CTRs propagating signals to the NTS and lateral parabrachial nucleus and then onto the amygdala and the bed nucleus of the stria terminalis of the forebrain, a key centre in regulating energy metabolism (Fig. 1).17,18 Chronically elevated doses of amylin fail to induce hypophagia in rats with lesions in the AP. ${ }^{19}$ Similarly, when the amylin receptor antagonist AC 187 is infused directly into the AP of rats, food intake is increased..$^{18,20}$

However, higher than normal doses of amylin can induce hypophagia in rats with AP lesions by activating other regions of the central nervous system. In addition to the AP, amylin also binds to receptors located in the arcuate nucleus (ARC) of the hypothalamus to synergise with leptin to phosphorylate STAT3 pathways in the ARC and ventromedial hypothalamic nuclei. ${ }^{21}$ Independent of leptin, amylin also activates proopiomelanocortin neurons, a critical regulator of neurons, through extracellular-signal regulated kinases signalling. ${ }^{16,21}$

\section{SYNTHETIC AMYLIN ANALOGUES}

Amylin appears to be an attractive target for inducing weight loss and glucose stabilisation. However, this is challenging due to the short acting nature of amylin as well as its tendency to self-aggregate. ${ }^{22}$ To overcome this, pramlintide, a long acting synthetic analogue, was developed with proline substitutions at positions 25,28 , and 29 to prevent aggregation. ${ }^{23,24}$ As amylin is an incretin hormone, pramlintide was developed to treat hyperglycaemia in both type 1 and type 2 diabetes mellitus (T2DM) patients. ${ }^{25}$ As such, the use of pramlintide in this context is associated with a reduction in glycosylated hemoglobin (HbAlc) as well as modest weight loss. ${ }^{26-28}$ To this end, early clinical trials demonstrated a decrease in body weight in people with obesity when treated with pramlintide (Table 1). ${ }^{12,29,30}$ In individuals with suboptimal glycaemic control in the setting of type 1 diabetes mellitus, pramlintide successfully lowered $\mathrm{HbAlc}$ through inhibition of glucagon secretion (a native hormone that liberates glucose from glycogen stores in the body). When administered in combination with basal insulin, pramlintide lowers $\mathrm{HbAlc}$ to a significantly greater extent than does basal insulin alone. ${ }^{28}$ 
Table 1. Baseline characteristics of trials included in this review

\begin{tabular}{|c|c|c|c|c|c|c|c|c|c|}
\hline Study & $\begin{array}{l}\text { Study duration, } \\
\text { Hawken et al. } \\
(2019)^{17}\end{array}$ & Blinding & Study arm & $\begin{array}{c}\text { Number of } \\
\text { patients } \\
\text { randomized }\end{array}$ & $\begin{array}{c}\mathrm{BMl} \\
\left(\mathrm{kg} / \mathrm{m}^{2}\right)\end{array}$ & $\begin{array}{l}\text { Body weight } \\
\quad(\mathrm{kg})\end{array}$ & $\begin{array}{c}\text { Age (yr), } \\
\text { Hawken et } \\
\text { al. }(2019)^{17}\end{array}$ & $\begin{array}{c}\text { Female } \\
(\%)\end{array}$ & $\begin{array}{c}\text { Significant loss } \\
\text { in body weight } \\
\text { vs. placebo }\end{array}$ \\
\hline $\begin{array}{l}\text { Smith et al. } \\
(2008)^{12}\end{array}$ & 16 & $\begin{array}{l}\text { Double-blind, } \\
\text { placebo } \\
\text { controlled }\end{array}$ & $\begin{array}{l}120 \mu \mathrm{g} \text { pramlintide bid } \\
240 \mu \mathrm{g} \text { pramlintide bid } \\
360 \mu \mathrm{g} \text { pramlintide bid } \\
120 \mu \mathrm{g} \text { pramlintide tid } \\
240 \mu \mathrm{g} \text { pramlintide tid } \\
360 \mu \mathrm{g} \text { pramlintide tid } \\
\text { Placebo }\end{array}$ & $\begin{array}{l}38 \\
38 \\
32 \\
45 \\
49 \\
42 \\
36\end{array}$ & $\begin{array}{l}37.5 \pm 5.0 \\
37.7 \pm 5.1 \\
38.1 \pm 5.4 \\
37.2 \pm 4.9 \\
37.8 \pm 5.5 \\
37.7 \pm 4.6 \\
37.2 \pm 4.4\end{array}$ & $\begin{array}{l}105.1 \pm 19.9 \\
105.6 \pm 18.0 \\
107.7 \pm 19.5 \\
104.7 \pm 19.2 \\
106.9 \pm 22.1 \\
108.1 \pm 17.2 \\
104.0 \pm 17.8\end{array}$ & $\begin{array}{l}43.0 \pm 11.0 \\
46.0 \pm 12.0 \\
45.0 \pm 14.0 \\
44.0 \pm 14.0 \\
44.0 \pm 12.0 \\
46.0 \pm 13.0 \\
47.0 \pm 12.0\end{array}$ & $\begin{array}{l}73 \\
71 \\
72 \\
75 \\
71 \\
73 \\
73\end{array}$ & $\begin{array}{l}\text { Yes } \\
\text { Yes } \\
\text { Yes } \\
\text { Yes } \\
\text { Yes } \\
\text { Yes } \\
\text { NA }\end{array}$ \\
\hline $\begin{array}{l}\text { Enebo et al. } \\
(2021)^{14}\end{array}$ & 20 & $\begin{array}{l}\text { Randomized, } \\
\text { placebo } \\
\text { controlled }\end{array}$ & $\begin{array}{l}0.16 \mathrm{mg} \text { cagrilintide+2. } 4 \mathrm{mg} \text { semaglutide } \\
0.30 \mathrm{mg} \text { cagrilintide }+2.4 \mathrm{mg} \text { semaglutide } \\
0.60 \mathrm{mg} \text { cagrilintide }+2.4 \mathrm{mg} \text { semaglutide } \\
1.20 \mathrm{mg} \text { cagrilintide }+2.4 \mathrm{mg} \text { semaglutide } \\
2.40 \mathrm{mg} \text { cagrilintide }+2.4 \mathrm{mg} \text { semaglutide } \\
4.50 \mathrm{mg} \text { cagrilintide }+2.4 \mathrm{mg} \text { semaglutide } \\
\text { Placebo+2.4 mg semaglutide }\end{array}$ & $\begin{array}{l}12 \\
12 \\
12 \\
12 \\
12 \\
11 \\
24\end{array}$ & $\begin{array}{l}31.0 \pm 32.0 \\
30.8 \pm 2.3 \\
333 \pm 3.7 \\
32.6 \pm 4.4 \\
32.2 \pm 2.5 \\
33.0 \pm 4.2 \\
32.2 \pm 3.0\end{array}$ & $\begin{array}{r}93.0 \pm 10.6 \\
92.9 \pm 11.7 \\
9.3 \pm 11.7 \\
95.1 \pm 14.4 \\
92.1 \pm 11.9 \\
98.0 \pm 17.3 \\
99.6 \pm 15.6\end{array}$ & $\begin{array}{l}43.0 \pm 9.2 \\
38.4 \pm 10.4 \\
40.0 \pm 8.3 \\
41.3 \pm 11.1 \\
43.0 \pm 8.1 \\
37.0 \pm 9.7 \\
41.0 \pm 8.8\end{array}$ & $\begin{array}{l}33 \\
42 \\
50 \\
50 \\
58 \\
27 \\
33\end{array}$ & $\begin{array}{l}\text { No } \\
\text { No } \\
\text { No } \\
\text { Yes } \\
\text { Yes } \\
\text { Yes } \\
\text { NA }\end{array}$ \\
\hline $\begin{array}{l}\text { Riddle et al. } \\
(2007)^{28}\end{array}$ & 16 & $\begin{array}{l}\text { Double-blind, } \\
\text { placebo } \\
\text { controlled }\end{array}$ & $\begin{array}{l}120 \mu g \text { pramlintide bid or tid } \\
\text { Placebo }\end{array}$ & $\begin{array}{l}107 \\
105\end{array}$ & $\begin{array}{l}35.0 \pm 6.0 \\
35.0 \pm 5.0\end{array}$ & $\begin{array}{l}103.0 \pm 18.0 \\
103.0 \pm 18.0\end{array}$ & $\begin{array}{l}55.0 \pm 10.0 \\
55.0 \pm 9.0\end{array}$ & $\begin{array}{l}48 \\
54\end{array}$ & $\begin{array}{l}\text { Yes } \\
\text { NA }\end{array}$ \\
\hline $\begin{array}{l}\text { Smith et al. } \\
(2007)^{29}\end{array}$ & 6 & $\begin{array}{l}\text { Double-blind, } \\
\text { placebo } \\
\text { controlled }\end{array}$ & $\begin{array}{l}180 \mu g \text { before meals } \\
\text { Placebo }\end{array}$ & $\begin{array}{l}60 \\
28\end{array}$ & $\begin{array}{l}35.3 \pm 3.6 \\
36.3 \pm 4.7\end{array}$ & $\begin{array}{l}100.2 \pm 14.3 \\
103.2 \pm 17.8\end{array}$ & $\begin{array}{l}49.9 \pm 9.0 \\
51.0 \pm 8.0\end{array}$ & $\begin{array}{l}50 \\
50\end{array}$ & $\begin{array}{l}\text { Yes } \\
\text { NA }\end{array}$ \\
\hline $\begin{array}{l}\text { Aronne et al. } \\
(2007)^{30}\end{array}$ & 16 & $\begin{array}{l}\text { Double-blind, } \\
\text { placebo } \\
\text { controlled }\end{array}$ & $\begin{array}{l}240 \mu g \text { tid } \\
\text { Placebo }\end{array}$ & $\begin{array}{r}137 \\
67\end{array}$ & $\begin{array}{l}37.9 \pm 5.7 \\
37.6 \pm 5.5\end{array}$ & $\begin{array}{l}105.5 \pm 18.4 \\
104.9 \pm 19.1\end{array}$ & $\begin{array}{l}48.0 \pm 10.0 \\
19.0 \pm 10.0\end{array}$ & $\begin{array}{l}80 \\
81\end{array}$ & $\begin{array}{l}\text { Yes } \\
\text { NA }\end{array}$ \\
\hline $\begin{array}{l}\text { Lau et al. } \\
(2021)^{15}\end{array}$ & 26 & $\begin{array}{l}\text { Double-blind, } \\
\text { placebo } \\
\text { controlled }\end{array}$ & $\begin{array}{l}0.3 \mathrm{mg} \text { cagrilintide once weekly } \\
0.6 \mathrm{mg} \text { cagrilintide once weekly } \\
1.2 \mathrm{mg} \text { cagrilintide once weekly } \\
2.4 \mathrm{mg} \text { cagrilintide once weekly } \\
4.5 \mathrm{mg} \text { cagrilintide once weekly } \\
3.0 \mathrm{mg} \text { liraglutide qd } \\
\text { Placebo }\end{array}$ & $\begin{array}{r}101 \\
100 \\
102 \\
102 \\
101 \\
99 \\
101\end{array}$ & $\begin{array}{l}38.4 \pm 7.5 \\
37.2 \pm 6.9 \\
37.1 \pm 6.2 \\
37.9 \pm 7.6 \\
38.4 \pm 7.7 \\
38.4 \pm 7.4 \\
37.1 \pm 5.7\end{array}$ & $\begin{array}{l}109.8 \pm 25.1 \\
106.2 \pm 23.8 \\
104.4 \pm 21.5 \\
106.8 \pm 24.1 \\
111.0 \pm 28.6 \\
107.8 \pm 24.1 \\
106.2 \pm 21.6\end{array}$ & $\begin{array}{l}53.5 \pm 10.3 \\
53.2 \pm 11.0 \\
52.1 \pm 8.7 \\
52.7 \pm 9.8 \\
51.5 \pm 12.7 \\
51.5 \pm 59.3 \\
51.4 \pm 11.9\end{array}$ & $\begin{array}{l}55 \\
62 \\
63 \\
75 \\
56 \\
65 \\
59\end{array}$ & $\begin{array}{l}\text { Yes } \\
\text { Yes } \\
\text { Yes } \\
\text { Yes } \\
\text { Yes* } \\
\text { NA } \\
\text { NA }\end{array}$ \\
\hline
\end{tabular}

Values are presented as mean \pm standard deviation.

* Significant weight loss was achieved versus placebo and liraglutide arms in the context of a comparable weight loss trial.

$\mathrm{BMI}$, body mass index; bid, twice a day; tid, three times a day; qd, once a day.

AM833 (cagrilintide) is a new investigational drug that exhibited some promising results in a recently completed phase II clinical trial for treatment of obesity. ${ }^{15}$ In this 26-week blinded phase 2 monotherapy trial, 706 people with obesity or overweight with at least one weight-related comorbidity and without history of diabetes were randomized to six active treatment arms including once-weekly cagrilintide at one of five doses $(0.3,0.6,1.2,2.4$, or $4.5 \mathrm{mg} ; \mathrm{n}=100$ 102 per arm), once-daily liraglutide $3.0 \mathrm{mg}(\mathrm{n}=99)$, or their volume-matched placebo arms $(n=101)$. Cagrilintide resulted in more significant weight loss at all doses (0.3-4.5 mg, 6.0\%-10.8\% [6.4$11.5 \mathrm{~kg}])$ versus placebo $(3.0 \%[3.3 \mathrm{~kg}], P<0.001)$ and at $4.5 \mathrm{mg}$ doses versus liraglutide $3.0 \mathrm{mg}(10.8 \%$ [11.5 kg] vs. $9.0 \%$ [9.6 kg], $P=0.03$ ) over 26 weeks. ${ }^{15}$ On the cagrilintide $4.5 \mathrm{mg}$ arm, $88.7 \%$ of participants achieved $\geq 5 \%$ weight loss and $53.5 \%$ of patients achieved $\geq 10 \%$ weight loss over 26 weeks (Table 1). ${ }^{15}$

From a structural viewpoint, AM833 (cagrilintide) is very similar in sequence to pramlintide with differences in lipidation of the $\mathrm{N}$-terminal lysine as well as substitutions of three amino acids (N14E, V17R, and P37Y) responsible for AM833 (cagrilintide), a non-selective AMYR and CTR agonist that can dually activate both class of receptors. This can promote greater weight loss in comparison with pramlintide. ${ }^{13}$

\section{AMYLIN AND GLP-1 COMBINATION THERAPY}

GLP-1 is a 37-amino acid peptide hormone released by enteroendocrine $\mathrm{L}$ cells of the distal small intestine in response to intralu- 
minal contents. ${ }^{31}$ Known for their incretin effects, synthetic GLP-1 analogues, namely liraglutide and semaglutide, have been developed for treatment of T2DM and obesity. ${ }^{32,33}$ Like amylin, GLP-1 is a potent satiety hormone, acting on receptors in the ARC in the hypothalamus, the $\mathrm{AP}$, and other appetite centres within the subcortical areas of the brain. ${ }^{34}$ GLP-1- and amylin receptor analoguedependent weight loss are mediated through both distinct and overlapping neural pathways. To this end, combined therapy might yield a synergistic effect with respect to both glycaemic control and weight loss. In rhesus monkeys, the GLP-1 and amylin analogues of exendin-4 and salmon calcitonin produced a synergistic reduction in food intake. ${ }^{35}$

An AM833 (cagrilintide) and semaglutide phase 1 combination trial over 20 weeks 14 tested six dosages of AM833 (cagrilintide; $0.16,0.3,0.6,1.2,2.4$, and $4.5 \mathrm{mg}$ ) versus placebo, alone and in combination with once-weekly subcutaneous semaglutide $2.4 \mathrm{mg}$. The drugs were administered in 95 individuals who were obese or classified as overweight (0.16-2.4 mg group, $\mathrm{n}=12$; $4.5 \mathrm{mg}$ group, $n=11)$ or placebo $(n=24)$. At week 20 , participants given cagrilintide $0.16-2.4 \mathrm{mg}$ in combination with semaglutide $2.4 \mathrm{mg}$ had achieved weight loss from $8.3 \%$ to $17.1 \%$. The greatest weight loss (17.1\%) was achieved with cagrilintide 1.2 or $2.4 \mathrm{mg}$ in combination with semaglutide $2.4 \mathrm{mg}$; pooled placebo in combination with semaglutide $2.4 \mathrm{mg}$ led to $9.8 \%$ weight loss (Table 1$){ }^{14}$

\section{SAFETY AND SIDE EFFECTS OF AMYLIN ANALOGUES}

Studies have shown that pramlintide therapy was generally welltolerated and safe, with no associated cardiovascular, pulmonary, hepatic, or renal toxicity. ${ }^{36,37}$ In terms of cardiovascular safety, the assessment of the frequency of major adverse cardiovascular events showed that pramlintide therapy is not associated with increased risk of cardiovascular adverse events. ${ }^{38}$

The most common adverse events associated with pramlintide are gastrointestinal side-effects, particularly mild to moderate nausea which typically is temporary, dose-dependent, and easily managed. Constipation can also result due to the amylin analogue effects on slowing gastric emptying. ${ }^{36-38}$ The mentioned side effects are similar to those of GLP-1 agonists and can be managed by pro- longing the dose escalation period, sufficient hydration, and reassurance. ${ }^{36-38}$

Clinical trials on AM833 (cagrilintide) have demonstrated its safe and well-tolerated profile. Serious adverse events were few and not dependent on cagrilintide dose. ${ }^{14,15}$ The severity of gastrointestinal disorders observed for the combination of AM833 and semaglutide was comparable to that of GLP-1 in monotherapy. ${ }^{14,15}$

\section{CONCLUSION}

Amylin analogues can be considered as a potent, efficient, and safe treatment option for obesity. The preliminary results of recent clinical trials support the benefits of combination therapy of amylin analogues with GLP-1 agonists to achieve greater weight loss in comparison with mono-therapy. Therefore, our review highlights the importance of conducting more clinical trials with larger samples to demonstrate the efficacy and safety of these promising therapeutic agents in obesity management.

\section{CONFLICTS OF INTEREST}

The authors declare no conflict of interest.

\section{AUTHOR CONTRIBUTIONS}

Study concept and design: all authors; acquisition of data: BD and NRSS; analysis and interpretation of data: BD and NRSS; drafting of the manuscript: all authors; critical revision of the manuscript: all authors; statistical analysis: BD and NRSS; obtained funding: CWLR; administrative, technical, or material support: BD and NRSS; and study supervision: CWLR.

\section{REFERENCES}

1. Puhl RM, Heuer CA. Obesity stigma: important considerations for public health. Am J Public Health 2010;100:1019-28.

2. Miras $\mathrm{AD}$, le Roux CW. Mechanisms underlying weight loss after bariatric surgery. Nat Rev Gastroenterol Hepatol 2013; 10:575-84.

3. Al-Najim W, Docherty NG, le Roux CW. Food intake and 
eating behavior after bariatric surgery. Physiol Rev 2018;98: 1113-41.

4. Züger D, Forster K, Lutz TA, Riediger T. Amylin and GLP-1 target different populations of area postrema neurons that are both modulated by nutrient stimuli. Physiol Behav 2013;112113:61-9.

5. Mietlicki-Baase EG. Amylin-mediated control of glycemia, energy balance, and cognition. Physiol Behav 2016;162:130-40.

6. Hay DL, Chen S, Lutz TA, Parkes DG, Roth JD. Amylin: pharmacology, physiology, and clinical potential. Pharmacol Rev 2015;67:564-600.

7. Sadry SA, Drucker DJ. Emerging combinatorial hormone therapies for the treatment of obesity and T2DM. Nat Rev Endocrinol 2013;9:425-33.

8. Schmitz O, Brock B, Rungby J. Amylin agonists: a novel approach in the treatment of diabetes. Diabetes 2004;53 Suppl 3:S233-8.

9. Mietlicki-Baase EG, Hayes MR. Amylin activates distributed CNS nuclei to control energy balance. Physiol Behav 2014; 136:39-46.

10. Lutz TA. The role of amylin in the control of energy homeostasis. Am J Physiol Regul Integr Comp Physiol 2010;298: R1475-84.

11. Ogawa A, Harris V, McCorkle SK, Unger RH, Luskey KL. Amylin secretion from the rat pancreas and its selective loss after streptozotocin treatment. J Clin Invest 1990;85:973-6.

12. Smith SR, Aronne LJ, Burns CM, Kesty NC, Halseth AE, Weyer C. Sustained weight loss following 12-month pramlintide treatment as an adjunct to lifestyle intervention in obesity. Diabetes Care 2008;31:1816-23.

13. Fletcher MM, Keov P, Truong TT, Mennen G, Hick CA, Zhao $\mathrm{P}$, et al. AM833 is a novel agonist of calcitonin family $\mathrm{G}$ protein-coupled receptors: pharmacological comparison with six selective and nonselective agonists. J Pharmacol Exp Ther 2021;377:417-40.

14. Enebo LB, Berthelsen KK, Kankam M, Lund MT, Rubino DM, Satylganova A, et al. Safety, tolerability, pharmacokinetics, and pharmacodynamics of concomitant administration of multiple doses of cagrilintide with semaglutide $2.4 \mathrm{mg}$ for weight management: a randomised, controlled, phase $1 \mathrm{~b}$ trial. Lancet
2021;397:1736-48.

15. Lau DC, Erichsen L, Francisco AM, Satylganova A, le Roux CW, McGowan B, et al. Once-weekly cagrilintide for weight management in people with overweight and obesity: a multicentre, randomised, double-blind, placebo-controlled and active-controlled, dose-finding phase 2 trial. Lancet 2021;398: 2160-72.

16. Boccia L, Gamakharia S, Coester B, Whiting L, Lutz TA, Le Foll C. Amylin brain circuitry. Peptides 2020;132:170366.

17. Hawken ER, Normandeau CP, Gardner Gregory J, Cécyre B, Bouchard JF, Mackie K, et al. A novel GPR55-mediated satiety signal in the oval Bed Nucleus of the Stria Terminalis. Neuropsychopharmacology 2019;44:1274-83.

18. Mollet A, Gilg S, Riediger T, Lutz TA. Infusion of the amylin antagonist AC 187 into the area postrema increases food intake in rats. Physiol Behav 2004;81:149-55.

19. Lutz TA, Mollet A, Rushing PA, Riediger T, Scharrer E. The anorectic effect of a chronic peripheral infusion of amylin is abolished in area postrema/nucleus of the solitary tract (AP/ NTS) lesioned rats. Int J Obes Relat Metab Disord 2001;25: 1005-11.

20. Lutz TA. Control of food intake and energy expenditure by amylin-therapeutic implications. Int J Obes (Lond) 2009;33 Suppl 1:S24-7.

21. Lutz TA, Coester B, Whiting L, Dunn-Meynell AA, Boyle CN, Bouret SG, et al. Amylin selectively signals onto POMC neurons in the arcuate nucleus of the hypothalamus. Diabetes 2018;67:805-17.

22. Qiu WQ, Zhu H. Amylin and its analogs: a friend or foe for the treatment of Alzheimer's disease? Front Aging Neurosci 2014;6:186.

23. Roth JD, Erickson MR, Chen S, Parkes DG. GLP-1R and amylin agonism in metabolic disease: complementary mechanisms and future opportunities. Br J Pharmacol 2012;166: 121-36.

24. Colburn WA, Gottlieb AB, Koda J, Kolterman OG. Pharmacokinetics and pharmacodynamics of AC137 (25,28,29 triproamylin, human) after intravenous bolus and infusion doses in patients with insulin-dependent diabetes. J Clin Pharmacol 1996;36:13-24. 
25. Hoogwerf BJ. Exenatide and pramlintide: new glucose-lowering agents for treating diabetes mellitus. Cleve Clin J Med 2006;73:477-84.

26. Hoogwerf BJ, Doshi KB, Diab D. Pramlintide, the synthetic analogue of amylin: physiology, pathophysiology, and effects on glycemic control, body weight, and selected biomarkers of vascular risk. Vasc Health Risk Manag 2008;4:355-62.

27. Purnell JQ, Weyer C. Weight effect of current and experimental drugs for diabetes mellitus: from promotion to alleviation of obesity. Treat Endocrinol 2003;2:33-47.

28. Riddle M, Frias J, Zhang B, Maier H, Brown C, Lutz K, et al. Pramlintide improved glycemic control and reduced weight in patients with type 2 diabetes using basal insulin. Diabetes Care 2007;30:2794-9.

29. Smith SR, Blundell JE, Burns C, Ellero C, Schroeder BE, Kesty NC, et al. Pramlintide treatment reduces 24-h caloric intake and meal sizes and improves control of eating in obese subjects: a 6-wk translational research study. Am J Physiol Endocrinol Metab 2007;293:E620-7.

30. Aronne L, Fujioka K, Aroda V, Chen K, Halseth A, Kesty NC, et al. Progressive reduction in body weight after treatment with the amylin analog pramlintide in obese subjects: a phase 2 , randomized, placebo-controlled, dose-escalation study. J Clin Endocrinol Metab 2007;92:2977-83.

31. Baggio LL, Drucker DJ. Biology of incretins: GLP-1 and GIP. Gastroenterology 2007;132:2131-57.

32. Gallwitz B. Glucagon-like peptide-1 analogues for type 2 dia- betes mellitus: current and emerging agents. Drugs 2011;71: 1675-88.

33. Knudsen LB, Lau J. The discovery and development of liraglutide and semaglutide. Front Endocrinol (Lausanne) 2019; 10:155.

34. Secher A, Jelsing J, Baquero AF, Hecksher-Sørensen J, Cowley MA, Dalbøge LS, et al. The arcuate nucleus mediates GLP-1 receptor agonist liraglutide-dependent weight loss. J Clin Invest 2014;124:4473-88.

35. Bello NT, Kemm MH, Ofeldt EM, Moran TH. Dose combinations of exendin- 4 and salmon calcitonin produce additive and synergistic reductions in food intake in nonhuman primates. Am J Physiol Regul Integr Comp Physiol 2010;299: R945-52.

36. Qiao YC, Ling W, Pan YH, Chen YL, Zhou D, Huang YM, et al. Efficacy and safety of pramlintide injection adjunct to insulin therapy in patients with type 1 diabetes mellitus: a systematic review and meta-analysis. Oncotarget 2017;8:66504-15.

37. Herrmann K, Frias JP, Edelman SV, Lutz K, Shan K, Chen S, et al. Pramlintide improved measures of glycemic control and body weight in patients with type 1 diabetes mellitus undergoing continuous subcutaneous insulin infusion therapy. Postgrad Med 2013;125:136-44.

38. Herrmann K, Zhou M, Wang A, de Bruin T. Cardiovascular safety assessment of pramlintide in type 2 diabetes: results from a pooled analysis of five clinical trials. Clin Diabetes Endocrinol 2016;2:12. 